\title{
A malignant differential diagnosis for Peyronie's disease
}

\author{
Manoj Kumar Gupta, ${ }^{1}$ Swaroop Revannasiddaiah, ${ }^{2}$ Sridhar Papaiah Susheela ${ }^{3}$
}

${ }^{1}$ Regional Cancer Centre, Indira Gandhi Medical College,

Shimla, India

${ }^{2}$ Department of Radiation

Oncology, Swami Rama Cancer Hospital and Research

Institute, Haldwani,

Uttarakhand, India

${ }^{3}$ Department of Radiation

Oncology, HealthCare Global-

Bangalore Institute of

Oncology, Bengaluru,

Karnataka, India

\section{Correspondence to}

Dr Swaroop Revannasiddaiah, swarooptheone@gmail.com

Accepted 16 March 2014

\section{(a) CrossMark}

To cite: Gupta MK, Revannasiddaiah $\mathrm{S}$, Susheela SP. BMJ Case Rep Published online: [please include Day Month Year] doi:10.1136/bcr-2013201446

\section{DESCRIPTION}

A healthy 36-year-old man reported with an abnormal penile erection where the erection curved to the right which he was noticed 6 months ago. He was diagnosed to be suffering from Peyronie's disease (induratio penis plastica) ${ }^{1}$ by an urologist, who had performed clinical palpation, and had obtained confirmation via the use of ultrasonography and the intracavernosal injection test. Since the condition did not affect his sexual functions, he was offered no treatment.

However, after a lapse of 2 months, he presented with breathlessness and haemoptysis. Evaluation revealed a mass in the right lung (figure 1) which on biopsy yielded an epidermal growth factor receptor mutated adenocarcinoma. A whole-body 18F-fluoro-deoxy-glucose positron emission tomography (FDG-PET) scan revealed the disease to be disseminated to multiple sites including the liver, opposite lung and bilateral adrenal glands.

A surprise finding was of a highly avid metastatic focus (standardised uptake value (SUV): 14.6) in the penis (figure 2) which had been the cause of his curved penile erections. Cytological confirmation of the penile lesion was not resorted to since the extremely high FDG-avidity (SUV 14.6) was,
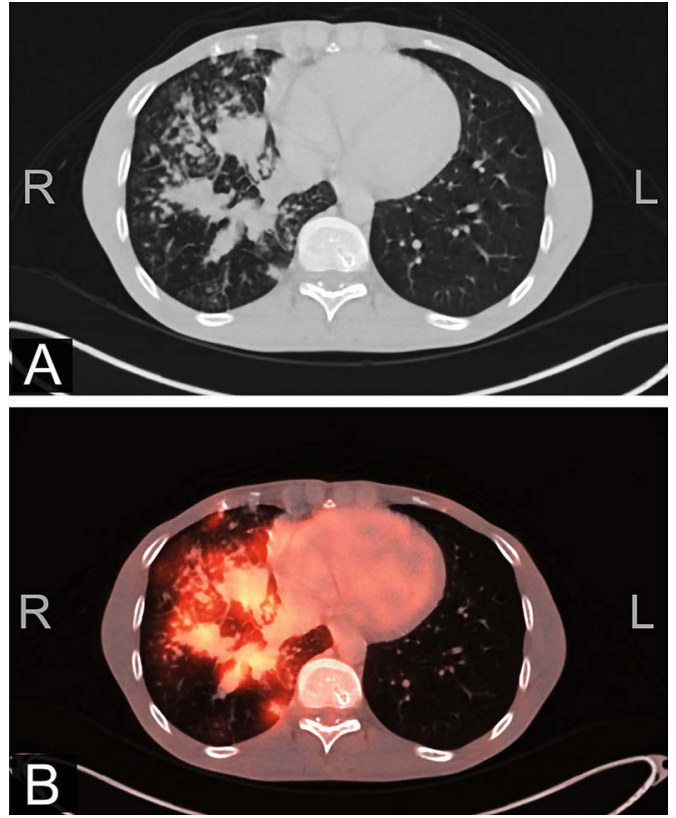

Figure $1 \mathrm{CT}(\mathrm{A})$ and positron emission tomography (B) demonstrating the metabolically active malignancy in the right lung.

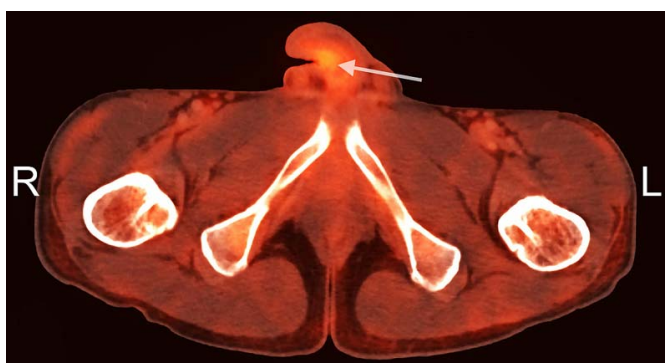

Figure 2 Positron emission tomography demonstrating a metabolically active lesion in the penis (arrow).

in-itself, confirmatory. This is a very rare instance where in a disseminated lung cancer case there has been a differential diagnosis of 'Peyronie's disease'.

Given the disseminated condition of malignancy and the fragile general condition of the patient, he was initiated on oral tyrosine-kinase inhibitor (erlotinib) as palliative treatment. However, 5 weeks after initiation of disease, the patient succumbed owing to respiratory failure due to bilateral metastatic pulmonary dissemination.

\section{Learning points}

- Peyronie's disease, also known as 'induratio penis plastica', is a disease wherein the presence of fibrous plaques leads to erectile difficulties and abnormal penile curvature.

- In rare situations, metastatic malignant disease to the penis may lead to the onset of sudden and abrupt symptomatology resembling Peyronie's disease.

- The use of FDG-PET scanning enables the detection of foci of distant metastases which may otherwise go unnoticed.

Contributors MKG wrote the manuscript. SR decided to report the case and provided the images. SPS prepared the final version of the manuscript.

Competing interests None.

Patient consent Obtained.

Provenance and peer review Not commissioned; externally peer reviewed.

\section{REFERENCE}

1 Gelbard MK, Dorey F, James K. The natural history of Peyronie's disease. J Urol 1990;144:1376-9. 


\section{Images in...}

Copyright 2014 BMJ Publishing Group. All rights reserved. For permission to reuse any of this content visit http://group.bmj.com/group/rights-licensing/permissions.

BMJ Case Report Fellows may re-use this article for personal use and teaching without any further permission.

Become a Fellow of BMJ Case Reports today and you can:

- Submit as many cases as you like

- Enjoy fast sympathetic peer review and rapid publication of accepted articles

- Access all the published articles

- Re-use any of the published material for personal use and teaching without further permission

For information on Institutional Fellowships contact consortiasales@bmjgroup.com

Visit casereports.bmj.com for more articles like this and to become a Fellow 